\title{
Conclave kindles hope for bioethical reform
}

Declan Butler, Paris

Questions raised by medical advances and the spread of AIDS will create significant challenges for the next Pope, say religious experts.

Such considerations will be important factors in the deliberations of this week's electing conclave. But will a new leader create scope within the Roman Catholic Church for a shift in thinking on these issues? Few expect any rapid change, in particular on the Church's 135-year dogma that human life begins at conception, and its consequent opposition to human stem-cell and embryo research (see 'When does life begin?'). But AIDS workers are hopeful that there may be room for manoeuvre when it comes to the new Pope's position on condom use.

John Paul II was one of the most sciencefriendly Popes yet (see Nature 434, 684; 2005). But this openness ended where sexual issues came into play. Despite the fact that his pontificate spanned the start of the AIDS pandemic, the discovery of HIV and the spread of the disease throughout Africa, John Paul took an ultraconservative stance on the use of condoms. He embraced Pope Paul VI's controversial 1968 encyclical Humanae Vitae, which was the Church's first explicit ban on contraception.

On the encyclical's 20th anniversary, John Paul said that no consideration could justify the use of contraception, arguing that chastity and research are the answers to controlling the AIDS epidemic. His message has been amplified around the world: evangelicals in the United States have made fidelity

\section{IMAGE \\ UNAVAILABLE FOR COPYRIGHT REASONS}

Catholic tastes: the Pope elected by this week's conclave may have more liberal views on condom use.

and abstinence prominent parts of President George W. Bush's African AIDS programmes, at the expense of efforts to promote condom use (see Nature 430, 279;2004).

Many AIDS workers argue that John Paul's active opposition to condoms damaged efforts to control the disease, especially in poor countries. "Policy differences with the Vatican on condom use are an issue of concern," says Ben Plumley of the Joint UN Programme on HIV/AIDS in Geneva. He explains that the Church has hampered the agency's attempts to educate people. Advice from the Vatican has at times contradicted scientific understanding - one senior Vatican official declared on television that HIV is

\section{When does life begin?}

The Roman Catholic Church has been a vigorous opponent of research on human embryos, including work on stem cells and therapeutic cloning. Despite lively debates, the next Pope is unlikely to change that.

The dogma that human life begins at the moment of conception was first introduced by Pope Pius IX in 1869. He put an end to centuries of thinking, inspired by Thomas Aquinas, which suggested that the embryo does not acquire a soul until later in its development.

There is scientific evidence that the moment of conception takes several hours, and that twins and triplets can form up to 14 hours afterwards. This continues to fuel debates in the Church about when 'ensoulment' occurs. But Gregory Robbins, a historian of religion at the University of Denver, Colorado, says he does not expect any softening on the issue from the successor to Pope John Paul II.

"Ensoulment, including the provision of souls for what will become twins or triplets, presumably takes place within the purview of God's foreknowledge," he says. "That does not seem to pose much of a theological problem. Embryonic and therapeutic stem-cell research do."

John Paul reiterated that life begins at fertilization in his 1995 Evangelium Vitae. The encyclical was based on an extensive scientific review of the literature commissioned from an international panel of scientists, says Roberto Colombo, who is head of genetics at the Catholic University of the Sacred Heart in Milan, Italy, and a member of the Pontifical Academy for Life - the Vatican's bioethics committee.

The Church concluded from the review, says Colombo, that although there are new hypotheses for markers of the beginning of a human - such as the first mitotic cell division or the appearance of an embryonic structure called the primitive streak - there is no consensus on these. The Church is therefore "resting on the solid ground of fertilization", Colombo says, adding that getting scientific consensus on alternative start points will probably take decades. small enough to pass through condoms (see Nature Medicine 9,1443 ; 2003). But, he adds, "the Church in recent years has shown willingness to debate the issue. We strongly encourage this."

John Paul's position was by no means accepted throughout the Church. Humanae Vitae's stance on contraception has been controversial from the outset and is ignored by many of the clergy, according to Timothy Thibodeau, an expert on Church history at Nazareth College in Rochester, New York. "Many of the cardinals from the developing world are at the 'ground zero' of AIDS," he says, and they see the dogma as divorced from reality.

As John Paul's grip on the Church diminished in his dying days, opposition to his AIDS policy surfaced. In February, Cardinal Georges Cottier, the Swiss theologian of the pontifical household, became the most senior church official to argue that condom use to prevent AIDS is "legitimate". Cottier says a theological case could be made for using condoms to prevent the spread of disease, while forbidding their use as contraceptives. The same position was adopted earlier in February by the Spanish bishops' conference in Madrid. And a relaxed stance on condoms for AIDS prevention is also supported by Cardinal Carlo Martini, archbishop of Milan, Italy.

As Nature went to press, no new Pope had been chosen. However, Thibodeau warns that even a Pope with liberal views will not endorse change lightly. The problem is not contraception as such, he points out, but the fact that it is wrapped up in a 'package deal' of teaching on human sexuality. Many in the church fear that relaxing dogma on contraception could trigger wider questions on topics such as marriage for priests and the notion of sex for pleasure. 